\title{
Synthesis of Conductive Cu-core / Ag-subshell / polyaniline-shell Nanocomposites and their Antimicrobial Activity
}

\author{
R.M. Mohsen ${ }^{1 *}$, S.M. M.Morsi ${ }^{1}$, Y. M. Abu-Ayana ${ }^{1}$, A. M. Ghoneim ${ }^{2}$ \\ ${ }^{1}$ Department of Polymers \& Piments, National Research Centre, 33 El Bohoth St. \\ (Former El Tahrir St.), Dokki, P.O. 12622, Giza, Egypt. Dokki, Cairo \\ ${ }^{2}$ Microwave Physics and Dielectric Department, National Research Centre, 33 El \\ Bohoth St. (Former El Tahrir St.), Dokki, P.O. 12622, Giza, Egypt. Dokki, Cairo
}

\begin{abstract}
CORE SHELL technique was used to synthesize conductive Cu-core / Ag-subshell / polyaniline-shell nanocomposites (NCs) and evaluating their antimicrobial activities. This was achieved through two stages, firstly different $\mathrm{Cu} / \mathrm{Ag}$ core shell nanoparticles $(\mathrm{Cu} / \mathrm{Ag} \mathrm{NPs})$ were prepared (C/A1, C/A3, C/A5), using electroless plating technique by reduction of $\mathrm{AgNO}_{3}$ in alcoholic dispersion of $\mathrm{Cu}$ NPs at three different weight ratios of $\mathrm{AgNO}_{3}: \mathrm{Cu}$. Secondly, the prepared $\mathrm{Cu} / \mathrm{Ag} \mathrm{NPs}$ were further coated with polyaniline (PANI) by oxidative polymerization of aniline in their aqueous dispersions to form PANI/(Cu/Ag) NCs (NC1, NC3, NC5). XRD patterns of $\mathrm{Cu} / \mathrm{Ag}$ NPs revealed their bimetallic crystalline structure. SEM micrographs and EDAX data proved formation of Ag thin shell on the surface of $\mathrm{Cu}$ core. The concentration of this silvery layer increased from $\approx 38 \%(\mathrm{C} / \mathrm{A} 1)$ to $68 \%$ (C/A5). SEM and EDAX data of NCs, showed that PANI film wrapped $60 \%$ to $63 \%$ of $\mathrm{Cu} / \mathrm{Ag}$ NPs surface that $\mathrm{Cu}$ nearly diminished. The synthesized NCs possessed good electrical conductivity that increased with Ag content from $0.52 \mathrm{~S} / \mathrm{m}$ (NC1) to13 (NC5) S/m. Good antimicrobial activities (antibacterial and antifungal), of $\mathrm{Cu} / \mathrm{Ag}$ NPs and their NCs were obtained. Such good conductivity and antimicrobial activity nominate the NCs to be applied in electronic and biotechnical fields.
\end{abstract}

Keywords: $\mathrm{Cu} / \mathrm{Ag}$ core shell nanoparticles, Polyaniline nanocomposites, Electrical conductivity, Antimicrobial activity.

\section{Introduction}

The use of nanoparticles (NPs) in different areas of life has recently spread, leading to increased research interest in these materials. Amongst these materials are metallic NPs, which occupied an important position for their wide range of application fields, especially in electronics and biotechnology, due to their superior physical and chemical properties [1-3]. Conductive polymer- metal nanocomposites (NCs) occupy superior position among nanostructure materials, due to their different application in electronic and biotechnology fields such as sensors [4,5], biosensors [6-8], corrosion protective coatings $[9,10]$, supercapacitors [11], and electromagnetic shielding devices [12]. They are mainly synthesized from polymer matrix through which metallic fillers are dispersed. Particles size (PS), concentration of matrix, fillers and their bond interactions, are some of many factors greatly affecting NCs properties [3]. PANI is considered the most promising conductive polymer due to its easy synthesis from cheap monomer, high electrical conductivity, and good stability $[4,13]$. The conductivity can be controlled by both doping process and type of dopant [14].

The most important metallic NPs are noble metals such as $\mathrm{Au}, \mathrm{Ag}$ and $\mathrm{Pt}$ [15]. The main difficulty in using non-noble metals such as Co, $\mathrm{Ni}, \mathrm{Fe}$ and $\mathrm{Cu}$ arises from their tendency towards oxidation at ambient conditions, particularly as their size gets smaller. Generally, Ag NPs is the most superior metal in conductivity and antimicrobial activity followed by copper $[3,16]$ but $\mathrm{Cu}$ is sometimes preferable taking into consideration cost factor. Commonly, metallic NPs are prepared by chemical reduction [1620] and electrochemical method [21], though various other techniques are involved including laser ablation [22], microwave irradiation [23],

*Corresponding author e-mail: rajiamohsen@yahoo.com

DOI: 10.21608/ejchem.2018.3969.1347

(C)2017 National Information and Documentation Centre (NIDOC) 
biosynthesis [24], sonochemical technique [25], and solvothermal colloidal method [26]. In fact each technique has the advantage and disadvantage, thus choosing the most appropriate method depends on the desired properties and specific applications. Other metallic nanostructures as bimetallic NPs such as, metal nanoalloys [27-30] and core/shell NPs [16,31-33] are of massive importance for their wide range of applications. The properties of bimetallic NAs and core / shell NPs differ from their single constituent metals [34]. Generally, $\mathrm{Ag}-\mathrm{Cu}$ nanoalloys possess excellent antibacterial and antiseptic characteristics [28-29] by destroying many types of bacteria, viruses and fungi that make them suitable for application in medicine and drug delivery fields [30]. Also, due to their superior electrical conductivity, they are used as sensors, corrosion resistance and composite fillers [27]. Commonly bimetallic nanoalloys can be prepared using chemical reduction and electrochemical method. However, electrochemical is considered the most practical and commercial method to make nanoalloys. Electrochemical method is mainly used for plating metal with more precious metal film. $\mathrm{As} \mathrm{Cu}$ is susceptible to oxidation on exposure to outer atmosphere, it may be protected by coating with $\mathrm{Ag}$ nanolayer $[3,16]$. This technique is superior to chemical reduction methods, involving strong reducing agents and organic stabilizers, as the particle size (PS) and shape of the NPs, can be controlled by varying the applied current density. Metals commonly employed for platings are silver, copper and nickel. Electroless plating is used for preparing bimetallic NPs by the deposition of metallic thin layer on the other without using electric current [3]. It can be expressed as core shell technique. Bimetallic $\mathrm{Cu} /$ Ag core / shell NPs occupy the most important position in such class of nanostructure materials mainly due to their tremendous conductive properties for conductive and decorative inks applications $[16,31,32]$. Several other studies for preparation $\mathrm{Cu} / \mathrm{Ag}$ NPs have been carried out, using electrodeposition thermal evaporation techniques under ultrahigh vacuum [32]. Excellent antibacterial and antiseptic characteristic of $\mathrm{Cu} / \mathrm{Ag}$ NPs nominates them in medical field application [33]. It is worthy to mention that as we discussed above the superior properties of coating the $\mathrm{Cu} / \mathrm{Ag}$ NPs by conductive polymer, it will also protect $\mathrm{Cu}$ from oxidation [32,35]. In this article, synthesis of Cu-core / Ag-subshell / PANI-shell NCs has carried out by coating
PANI on bimetallic $\mathrm{Cu} / \mathrm{Ag}$ NPs which have been prepared. Their electrical conductivity and antimicrobial activities were evaluated.

\section{Experimental}

Materials

Truncated cubical shape $\mathrm{Cu}$ NPs of particle size (PS) 1-10 nm (previously prepared and characterized by the authors) [3]. Silver nitrate $\mathrm{AgNO}_{3}$ was obtained from Sisco Research Laboratories PVT. Ltd. India. Hydrazine monohydrate $\mathrm{N}_{2} \mathrm{H}_{4} \mathrm{H}_{2} \mathrm{O} 64-65 \%$, reagent grade $98 \%$, was provided from Sigma-Aldrich. Ethylene glycol was obtained from SDFCL Fine Chemical Ltd.. Methyl alcohol 99\% was obtained from Sigma Chemicals. Sodium hydroxide pellets $99 \%$ was provided from Laboratory Chemicals, Modern Lab. Potassium persulfate $98 \%$ was obtained from Fischer Laboratory Reagent. Hydrochloric acid $35-38 \%$ was obtained from Fisher Scientific. Aniline monomer was obtained from Merck and distilled under reduced pressure before use.

\section{Methodology \\ Preparation of bimetallic Cu/Ag core shell NPS}

Bimetallic $\mathrm{Cu} / \mathrm{Ag}$ NPs were prepared by deposition of thin layer of Ag NPs on prepared $\mathrm{Cu} \mathrm{NPs}$, using electroless plating technique. In a typical process, $1 \mathrm{~g} \mathrm{Cu}$ NPs was dispersed in $30 \mathrm{ml}$ methanol by mechanical stirrer using 1 $\mathrm{g}$ ethylene glycol as stabilizing agent. Desired amount of $\mathrm{AgNO}_{3}(1 \mathrm{~g}, 3 \mathrm{~g}$ or $5 \mathrm{~g})$ was added to the reaction mixture and reduced by $10 \mathrm{~g}$ hydrazine monohydrate at $\mathrm{pH} 8-9$ to prepare $\mathrm{C} / \mathrm{A} 1, \mathrm{C} / \mathrm{A} 3$ and $\mathrm{C} / \mathrm{A} 5$, respectively. The prepared $\mathrm{Cu} / \mathrm{Ag} \mathrm{NPs}$ was filtred, washed by double distilled water and dried at room temperature.

Synthesis of conductive Cu-core / Ag-subshell / PANI-shell NCs (PANI/(Cu/Ag) NCs

PANI $/(\mathrm{Cu} / \mathrm{Ag})$ NCs was synthesized by oxidative polymerization of aniline in the presence of aqueous dispersed $\mathrm{Cu} / \mathrm{Ag}$ NPs. Typically, 3.75 $\mathrm{ml}$ aniline was dissolved in $100 \mathrm{ml}$ distilled water in which $1.5 \mathrm{~g} \mathrm{C} / \mathrm{A}$ NPs was dispersed using 1.5 $\mathrm{g}$ ethylene glycol as stabilizing agent. $3 \mathrm{~g} \mathrm{MHCl}$ (doping agent) was added to the reaction mixture with continous stirring using mechanical stirrer, followed by addition of $1.9 \mathrm{~g}$ potassium persulfate dissolved in $100 \mathrm{ml}$ distilled water. Dark greenish precipitate of $\mathrm{PANI} /(\mathrm{Cu} / \mathrm{Ag}) \mathrm{NC}$ was obtained, filtred, washed with doubled distilled water and dried at room temperature. $\mathrm{PANI} /(\mathrm{Cu} / \mathrm{Ag}) \mathrm{NCs}$ synthesized from $\mathrm{C} / \mathrm{A} 1, \mathrm{C} / \mathrm{A} 3$ and $\mathrm{C} / \mathrm{A} 5$ were 
symbolized as NC1, NC3 and NC5, respectively.

\section{Instrumental analysis}

XRD analysis

$\mathrm{X}$-ray power diffraction (XRD) patterns were recorded at room temperature using Philips PW 1390 Diffractometer using Ni-filter and Cuk radiation source $(\lambda=1.54 \AA$ ) $)$, Japan and operated at $40 \mathrm{kV}$ and $40 \mathrm{~mA}$ in the $2 \theta$ range $5-80^{\circ}$ at the scan speed of $0.05^{\circ}$ per second.

The average crystalline size D of NPs is estimated from Scherrer's equation 1 [27] :

$$
\mathrm{D}=\frac{\mathrm{K} \lambda}{\beta \cos \theta}
$$

where $\mathrm{K}$ is a shape factor constant equals to 0.9 , $\lambda$ is the wave length of X-ray radiation $1.54 \AA$ is the Bragg diffraction angle and $\beta$ is the angular line width at half of the maximum intensity (FWHM). The lattice strain $\varepsilon$ is calculated from equation 2 [36]:

$$
\varepsilon=\frac{\beta}{4 \tan \theta}
$$

\section{FTIR spectroscopy}

Fourier transform infrared (FTIR) spectra of sample/KBr pellets were recorded by JASCO FTIR 6100 in the range of $4000-400 \mathrm{~cm}^{-1}$.

Transmission electron microscopy analysis (TEM)

TEM micrographs were analyzed using High Resolution Transmission Electron Microscope JEOL-2100 TEM, USA.

\section{Scanning electron microscope (SEM)}

SEM photos were obtained by Quantum Field Emission Gun 250 SEM instrument with energydispersive X-ray spectroscopy (EDAX) system.

Electrical conductivity measurements

AC electrical conductivity was measured in S/m by Hioki 3522-50 LCR Hi Tester (Japan).

Antimicrobial activity measurements

Antibacterial and antifungus activities toward (Escherichia coli $\mathrm{G}^{-}$and Staphylococcus aureus $\mathrm{G}^{+}$) and (Asprigillus flavus and Candida albicans) were determined using modified Kirby- Bauer disc diffusion $[37,38]$. Measurements were carried out at "Micro Analytical Center", Faculty of Science - Cairo University.

\section{Results and Discussion}

The synthetic steps used to prepare $\mathrm{Cu} / \mathrm{Ag}$
NPs and PANI/(Cu/Ag) NC were presented in the schematic diagram displayed in Fig. 1.

\section{Characterization of $(\mathrm{Cu} / \mathrm{Ag} \mathrm{NPS})$ \\ $X R D$ of $\mathrm{Cu} / \mathrm{Ag} \mathrm{NPS}$}

Figure 2 shows the XRD diffractograms of the prepared bimetallic $\mathrm{Cu} / \mathrm{Ag}$ NPs $(\mathrm{C} / \mathrm{A} 1, \mathrm{C} / \mathrm{A} 3$, $\mathrm{C} / \mathrm{A} 5)$. The emergence of $\mathrm{Ag}$ and $\mathrm{Cu}$ remarkable peaks in XRD patterns pointed out crystalline formation of both metals. Clear and strong narrow diffraction peaks were obtained indicating high degree of crystallinity.The characteristic peaks of $\mathrm{Ag}$ emerged at diffraction angles $2 \theta=38.05$ $38.17^{\circ}(1 \mathrm{I} 1), 44.33-44.66^{\circ}$ (200), 64-64.57 ${ }^{\circ}$ (220), $77-78.33^{\circ}(311)$, and those related to $\mathrm{Cu}$ appeared at $2 \theta=43.28-43.38^{\circ}(1 \mathrm{I} 1), \quad 50.17-50.5^{\circ}$ (200), $74^{\circ}$ (220). They are well agreed with JCPDS standards of Ag NPs (No. 04-0783) and Cu NPs (No. 04-0836). The intensity of Ag diffraction peaks increased with increasing $\mathrm{Ag}$ content in $\mathrm{Cu} / \mathrm{Ag}$ NPs and vice versa with $\mathrm{Cu}$ peaks which decreased with increasing Ag content. Table 1 shows the crystallite diameter (D) and lattice strain (L.S.) of $\mathrm{Ag}$ and $\mathrm{Cu}$ NPs in the $\mathrm{Cu} / \mathrm{Ag}$ NPs. It shows that $\mathrm{D}$ of $\mathrm{Ag}$ increased from $11.2 \mathrm{~nm}$ in $\mathrm{C} / \mathrm{A} 1$ to $34.46 \mathrm{~nm}$ in $\mathrm{C} / \mathrm{A} 5$ while for $\mathrm{Cu}$ it decreased from $18.89 \mathrm{~nm}$ in C/A1 to $14.11 \mathrm{~nm}$ in C/A5. The lattice strain which arises due to crystal imperfection and distortion slightly decreased from $\mathrm{C} / \mathrm{A} 1$ to $\mathrm{C} / \mathrm{A} 5$.

\section{TEM of Cu/Ag NPs}

Figure 3 shows TEM images of C/A5 NPs. It reveals nearly rounded nanocrystals with diameter ranged from $10 \mathrm{~nm}$ to $30 \mathrm{~nm}$. Some corner-edged nanocrystals are included in the images.

\section{$N P S$ \\ SEM micrographs and EDAX analysis of $\mathrm{Cu} / \mathrm{Ag}$}

Figure 4 shows SEM micrographs and EDAX analysis of the synthesized $\mathrm{Cu} / \mathrm{Ag}$ NPs. EDAX data are given in Table 2. SEM image of C/A1 NPs reveals small spherical flocculates of Ag NPs capping $\mathrm{Cu}$ NPs. This silvery coat predominates in SEM photo of C/A5 NPs to appear covering the majority of $\mathrm{Cu}$ NPs. The EDAX profiles $\mathrm{Cu}$ atoms. The strong and medium signal energy peaks appeared at $2-4 \mathrm{KeV}$ is related to sphericalshaped Ag NPs [39]. The chacateristic strongest optical absorption peak of Ag NPs appeared at 3 $\mathrm{KeV}$ is due to surface Plasmon resonance [40]. Additionally, three peaks characteristic for $\mathrm{Cu}$ NPs are also observed at $\sim 0.85 \mathrm{KeV}$ representative to L-shell electron and at $\sim 8 \mathrm{KeV}$ and $8.9 \mathrm{KeV}$ emitted from K-shell electron. EDAX data are 

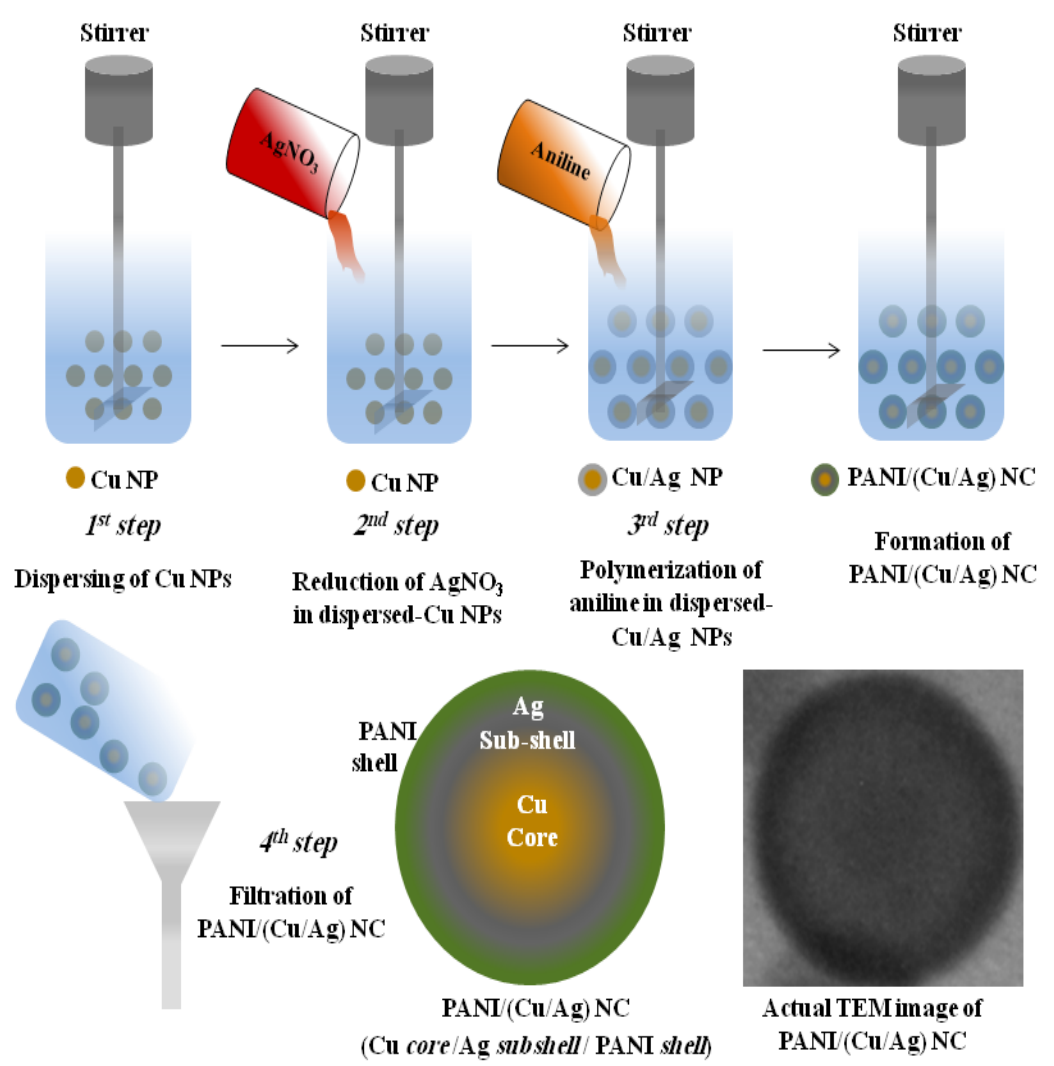

Fig. 1. Schematic diagram of the synthetic pathway used to prepare $\mathrm{Cu} / \mathrm{Ag}$ NPs and PANI/(Cu/Ag) NC.
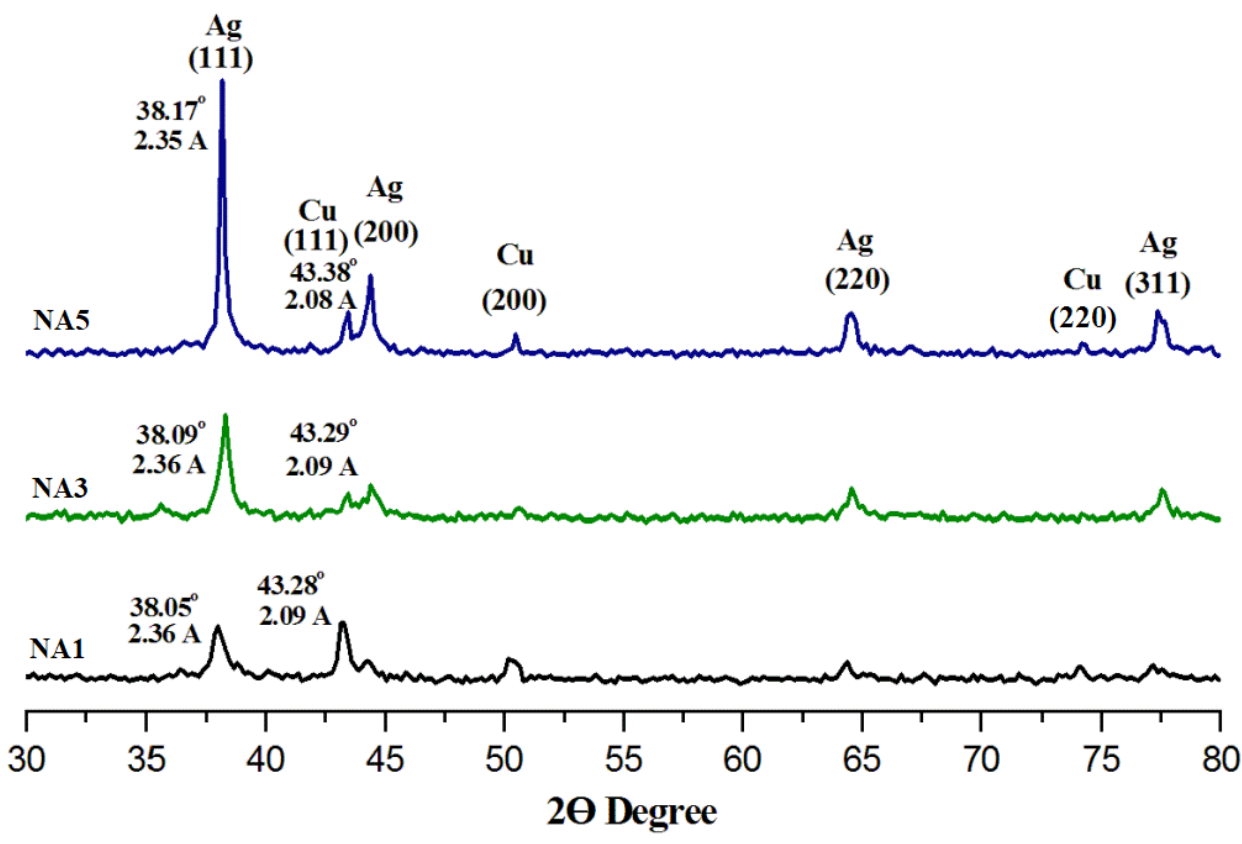

Fig. 2. XRD of $\mathrm{Cu} / \mathrm{Ag}$ NPs. 

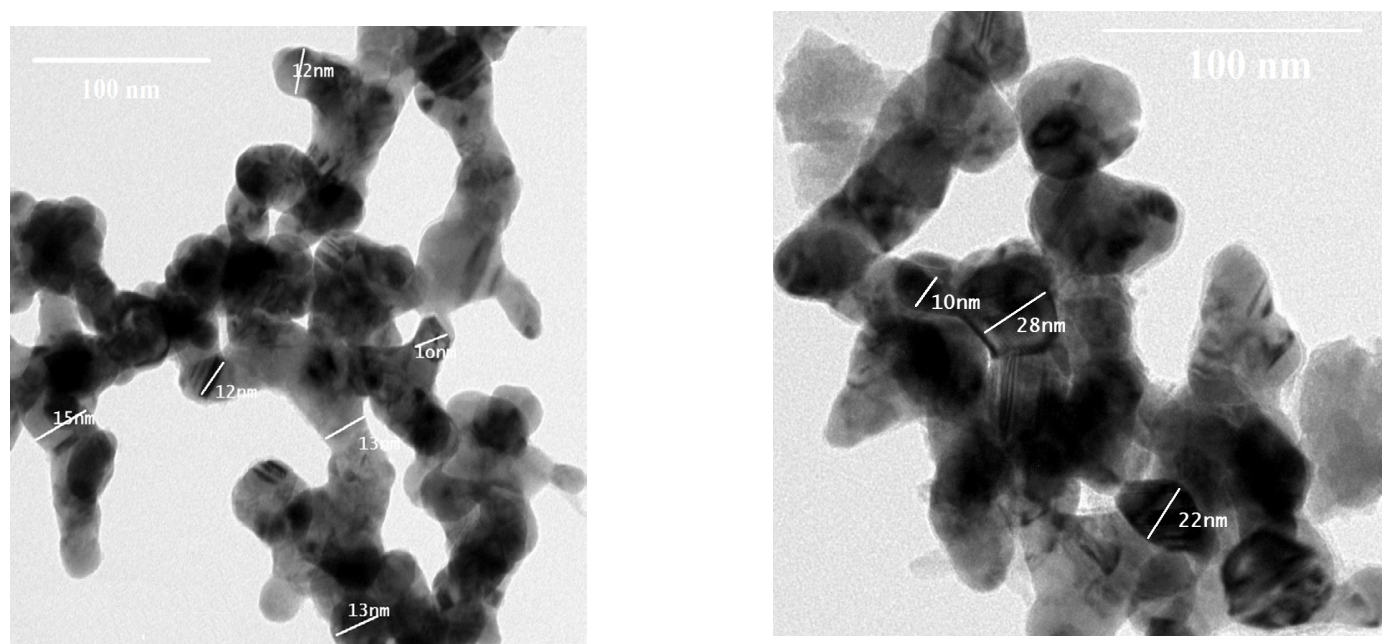

Fig. 3. TEM images of C/A5 NPs.
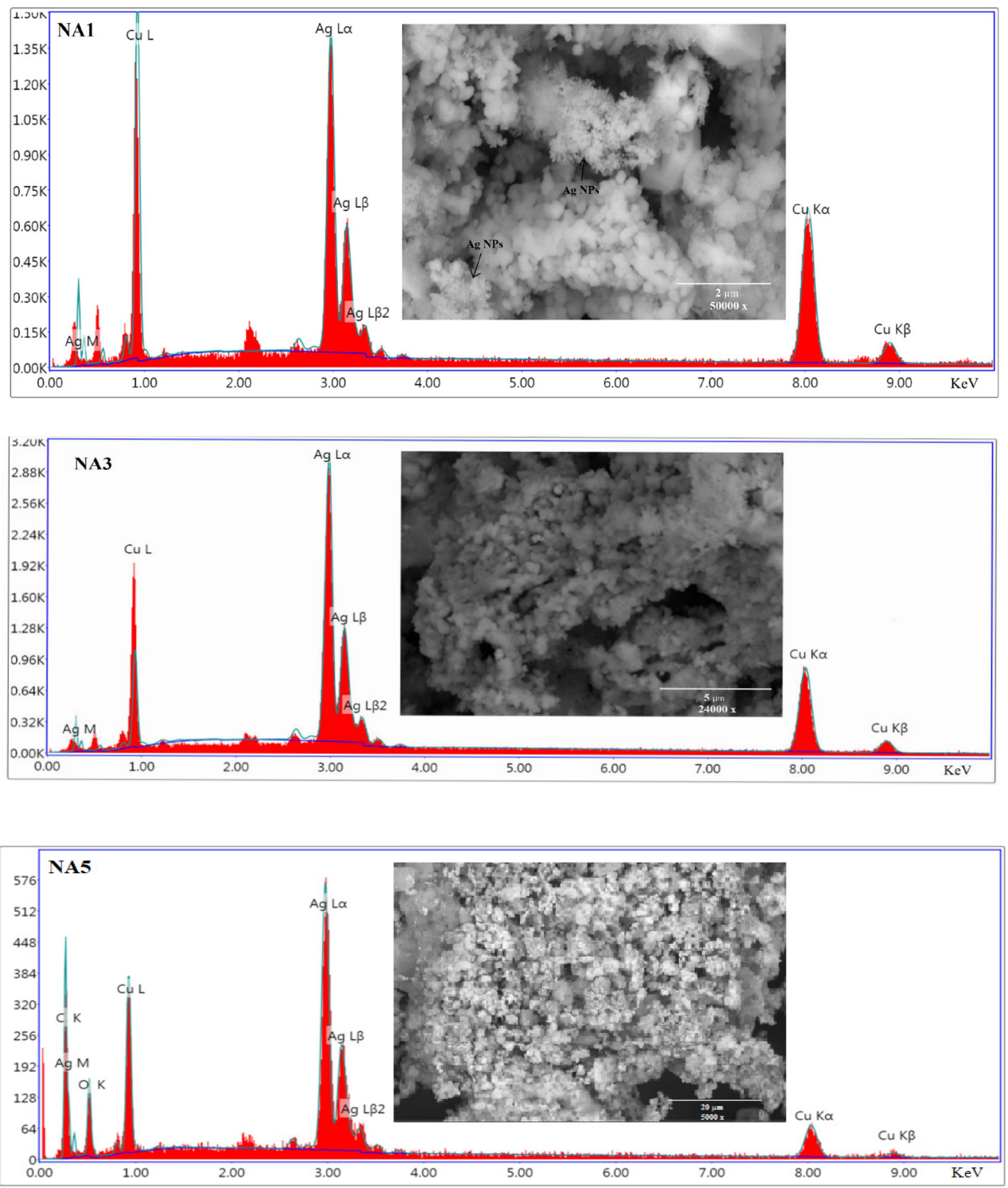

Fig. 4. SEM microographs and EDAX analysis of $\mathrm{Cu} / \mathrm{Ag}$ NPs.

Egypt. J. Chem. 61, No. 5 (2018) 
TABLE 1. Crystallite diameter (D) and lattic strain (L.S.) of in Cu/Ag NPs.

\begin{tabular}{ccccccc}
\hline \multirow{2}{*}{ Pea } & \multicolumn{3}{c}{ Ag (111) } & \multicolumn{3}{c}{ Cu (111) } \\
\cline { 2 - 7 } & C/A1 & C/A3 & C/A5 & C/A1 & C/A3 & C/A5 \\
\hline D & 11.2 & 14.96 & 34.46 & 18.89 & 15.65 & 14.11 \\
L.S. & 0.0099 & 0.0074 & 0.0032 & 0.0052 & 0.0063 & 0.0069 \\
\hline
\end{tabular}

TABLE 2. EDAX data of prepared Cu/Ag NPs.

\begin{tabular}{|c|c|c|c|c|}
\hline \multirow{3}{*}{$\begin{array}{l}\text { Reactants ratio } \\
\qquad \mathrm{AgNO}_{3}: \mathrm{Cu}\end{array}$} & \multicolumn{4}{|c|}{ EDAX of Cu/Ag NPs } \\
\hline & \multirow{2}{*}{$\mathrm{Cu} / \mathrm{Ag}$ NPs } & \multirow{2}{*}{$\begin{array}{c}\text { Ag:Cu wt. ratio on the } \\
\text { surface }\end{array}$} & \multicolumn{2}{|c|}{ wt. \% } \\
\hline & & & Ag & $\mathrm{Cu}$ \\
\hline $1: 1$ & $\mathrm{C} / \mathrm{A} 1$ & 0.615 & 38.1 & 61.9 \\
\hline $3: 1$ & $\mathrm{C} / \mathrm{A} 3$ & 0.996 & 49.9 & 50.1 \\
\hline $5: 1$ & $\mathrm{C} / \mathrm{A} 5$ & 2.195 & 68.7 & 31.3 \\
\hline
\end{tabular}

summarized in Table 2 show that as $\mathrm{AgNO}_{3}$ to $\mathrm{Cu}$ ratio increased from 1:1 to $5: 1, \mathrm{Ag} \%$ increased from 38.1 to 68.7 while $\mathrm{Cu} \%$ decreased from 61.9 to 31.3 .

\section{Characterization of synthesized PANI/(Cu/Ag) NCs FTIR spectra of the synthesized PANI/(Cu/Ag) NCs}

The FTIR spectra of the synthesized PANI/ $(\mathrm{Cu} / \mathrm{Ag}) \mathrm{NCs},(\mathrm{NC} 1, \mathrm{NC} 2$ and $\mathrm{NC5})$ are given in Fig.5. Since NCs are composed of PANI, Ag NPs and $\mathrm{Cu}$ NPs, therefore, PANI characteristic bands are the only one represented in the figure. $3406 \mathrm{~cm}^{-1}$ band is concerning to N-H stretching. 1562-1568 $\mathrm{cm}^{-1}$ and 1485-1498 $\mathrm{cm}^{-1}$ bands are related to $\mathrm{C}=\mathrm{C}$ stretchings of quinonoid $(\mathrm{N}=\mathrm{Q}=\mathrm{N})$ and benzenoid $(\mathrm{N}-\mathrm{B}-\mathrm{N})$ rings, respectively. $1305 \mathrm{~cm}^{-1}$ and $1225 \mathrm{~cm}^{-1}$ bands are assigned to $\mathrm{C}-\mathrm{N}$ stretchings of both secondary aromatic amine and polaron lattice, respectively. $\mathrm{C}-\mathrm{H}$ in-plane and out-of-plane bendings of 1,4 disubstituted aromatic rings appeared at $1130 \mathrm{~cm}^{-1}$ and $805 \mathrm{~cm}^{-1}$, respectively $[4,8]$.

\section{TEM of PANI /(Cu/Ag) NCs}

Figure 6 displays TEM photos of PANI/ $(\mathrm{Cu} /$ Ag) NC5. The images show clear spherical typical core-shell nanoscaled particles. The particles size ranged from $10 \mathrm{~nm}$ to $45 \mathrm{~nm}$ with the majority between $20 \mathrm{~nm}$ to $30 \mathrm{~nm}$. They consist of $\mathrm{Cu}$ core and bilayered shell of silver middle coat and PANI cover. Some small particulates are clearly observed in the images that may be related to a solo item of $\mathrm{Cu}$ core constituent.

SEM micrographs and EDAX analysis data of PANI /(Cu/Ag) NCs

Figure 7 shows SEM micrographs and EDAX analysis of $\mathrm{PANI} /(\mathrm{Cu} / \mathrm{Ag}) \mathrm{NCs}$. It revealed that PANI moderately coated $\mathrm{Cu} / \mathrm{Ag}$ core shell NPs. Some coagulated particles of Ag NPs are observed on the surface. Table 3 summarizes the EDAX analysis data, it shows that PANI coated most of the $\mathrm{Cu}$ present on surface, such that it is almost diminished. Also Ag layer were coated by PANI to some degree. Generally no marked variation in NCs surface composition is noticed, whereby the weight percent of PANI and Ag ranged from (60.3 to 63.6 ), and (35.8 to 39.0 ) respectively.

\section{Electrical conductivity}

Conductivities of synthesized PANI/(Cu/Ag) $\mathrm{NCs}$, are given in Table 4. They increase from $0.52 \mathrm{~S} / \mathrm{m}$ (in NC1) to $13 \mathrm{~S} / \mathrm{m}$ (in NC5). Generally, $\mathrm{NC} 3$ and NC5 gave high conductivity. This can be attributed to the increase of the relative $\mathrm{Ag}$ content to $\mathrm{Cu}$ in synthesized PANI/(Cu/Ag) NCs, as $\mathrm{Ag}$ is considered the most conductive metal on earth, due to single valence electron that makes it free to move around with little resistance. $\mathrm{Cu}$ also is considered one of the few metals that have this particular character, explaining their high 


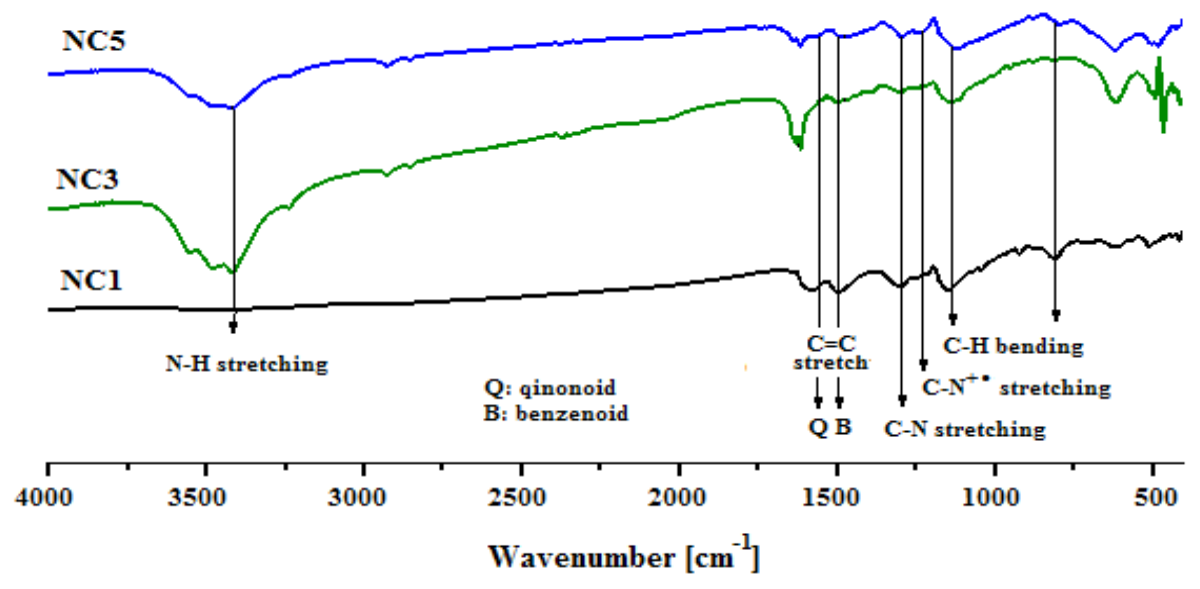

Fig. 5. FTIR spectra of PANI/(Cu/Ag) NCs.
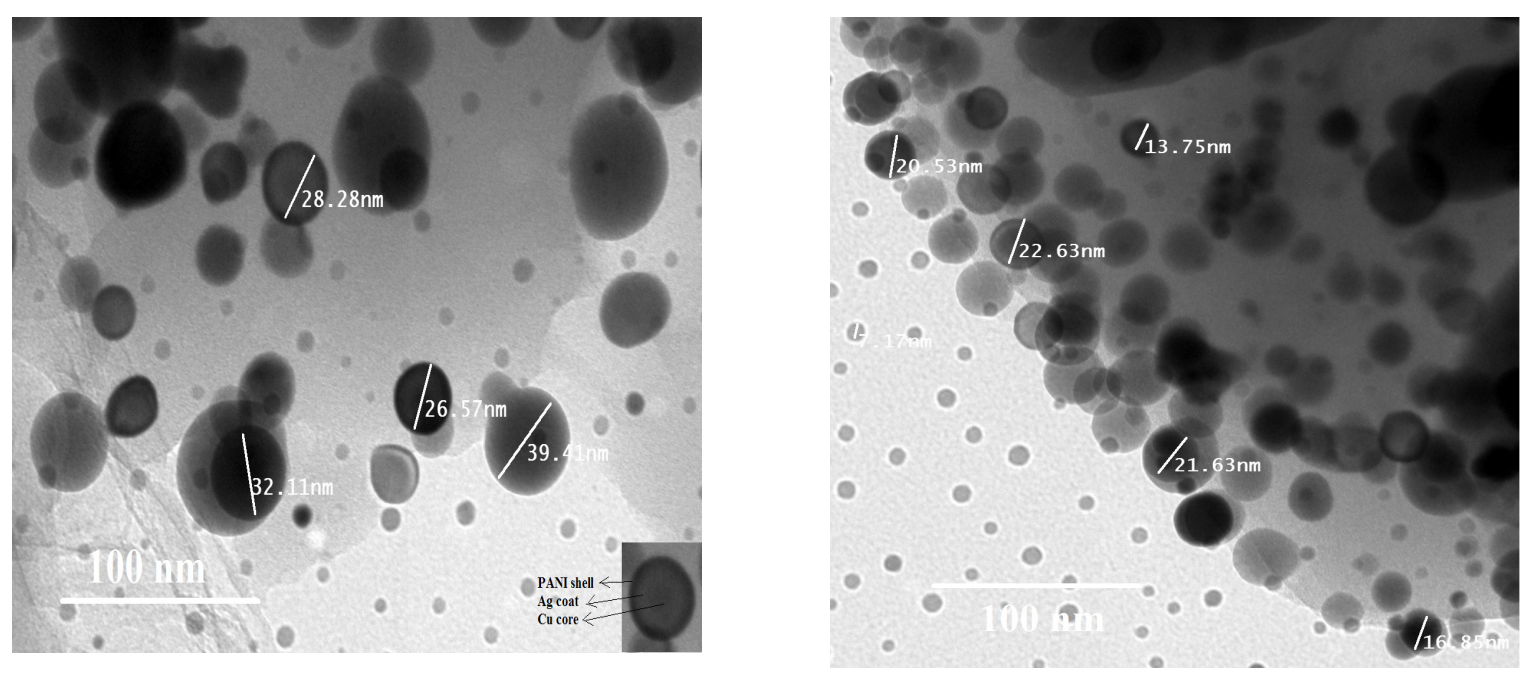

Fig. 6. TEM images of PANI/(Cu/Ag) NC5.

TABLE 3. EDAX data of synthesized PANI/(Cu/Ag) NCs.

\begin{tabular}{cccccccc}
\hline \multirow{2}{*}{$\begin{array}{c}\text { Reactants ratio } \\
\text { PANI:Cu/Ag NPs }\end{array}$} & $\begin{array}{c}\text { Dopped } \\
\text { PANI* }\end{array}$ & & \multicolumn{5}{c}{ EDAX of PANI/(Cu/Ag) NCs } \\
\cline { 3 - 7 } & & NCs & C & N & CI & Ag\% & Cu\% \\
\hline $2.55: 1$ & 63.6 & NC1 & 33.5 & 6.2 & 23.9 & 35.8 & 0.6 \\
$2.55: 1$ & 60.6 & NC3 & 29.6 & 5.1 & 25.9 & 38.9 & 0.5 \\
$2.55: 1$ & 60.3 & NC5 & 44.4 & 10.1 & 16.8 & 39.0 & 0.7 \\
\hline
\end{tabular}

*Approximate estimation of dopped PANI from EDAX of $\mathrm{C}, \mathrm{N}$ and $\mathrm{Cl}$. 


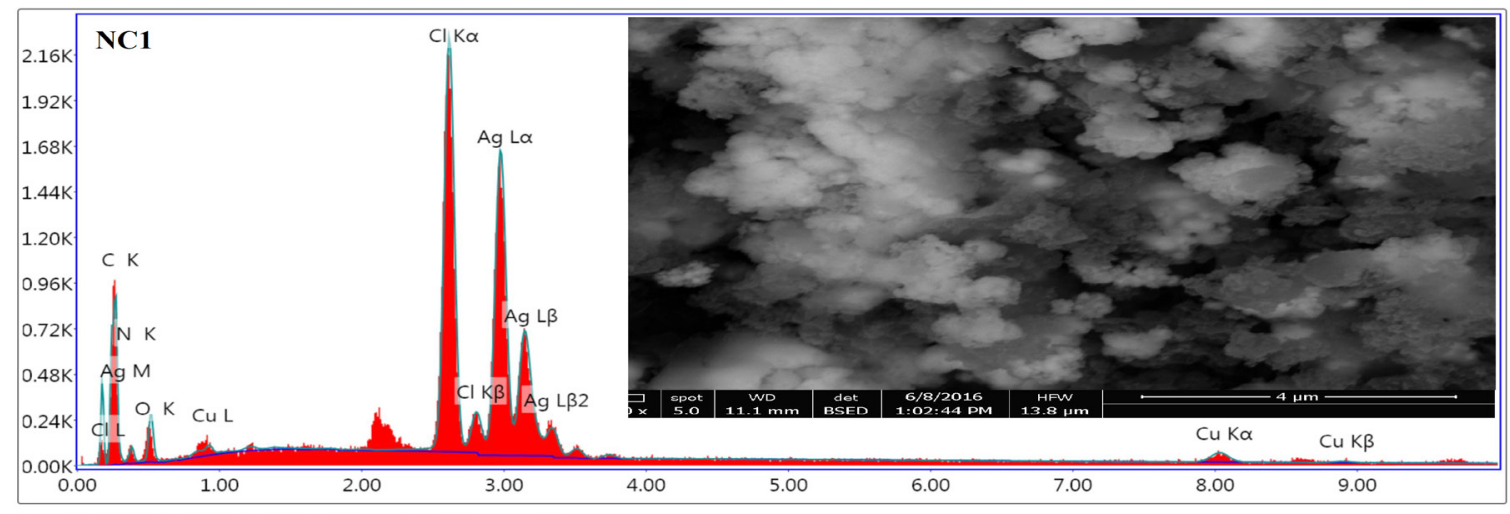

Lsec: 30.00 Cnts $0.000 \mathrm{keV}$ Det: Octane Pro Det Reso

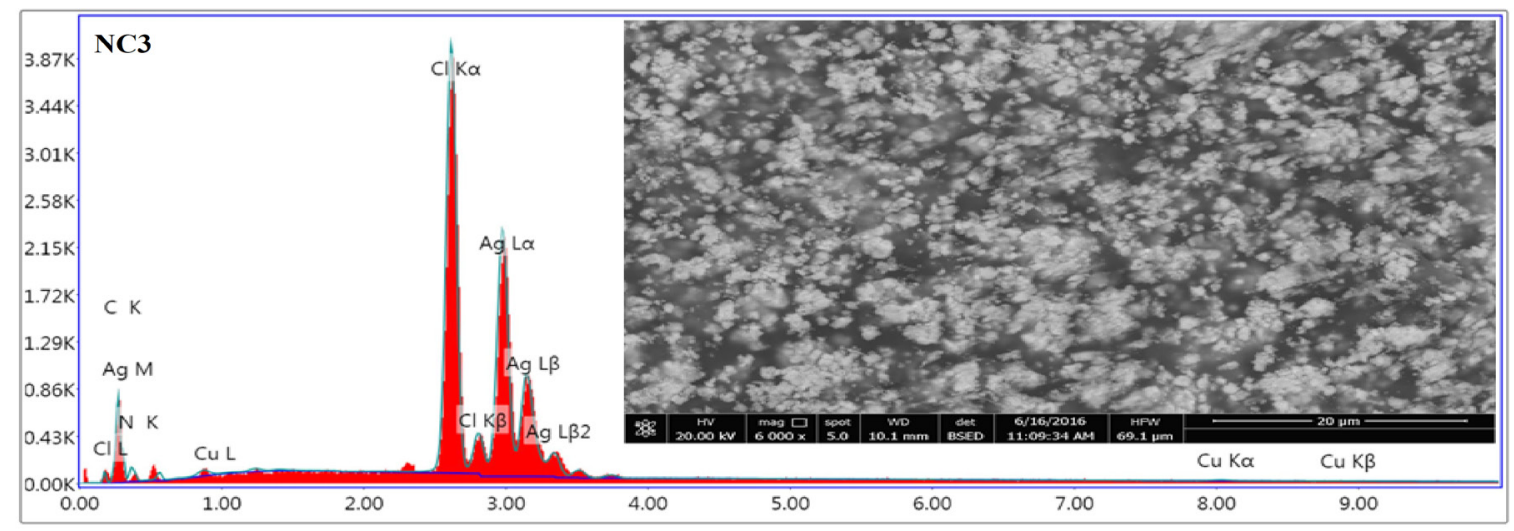

Lsec: 30.00 Cnts 0.000 keV Det: Octane Pro Det Reso

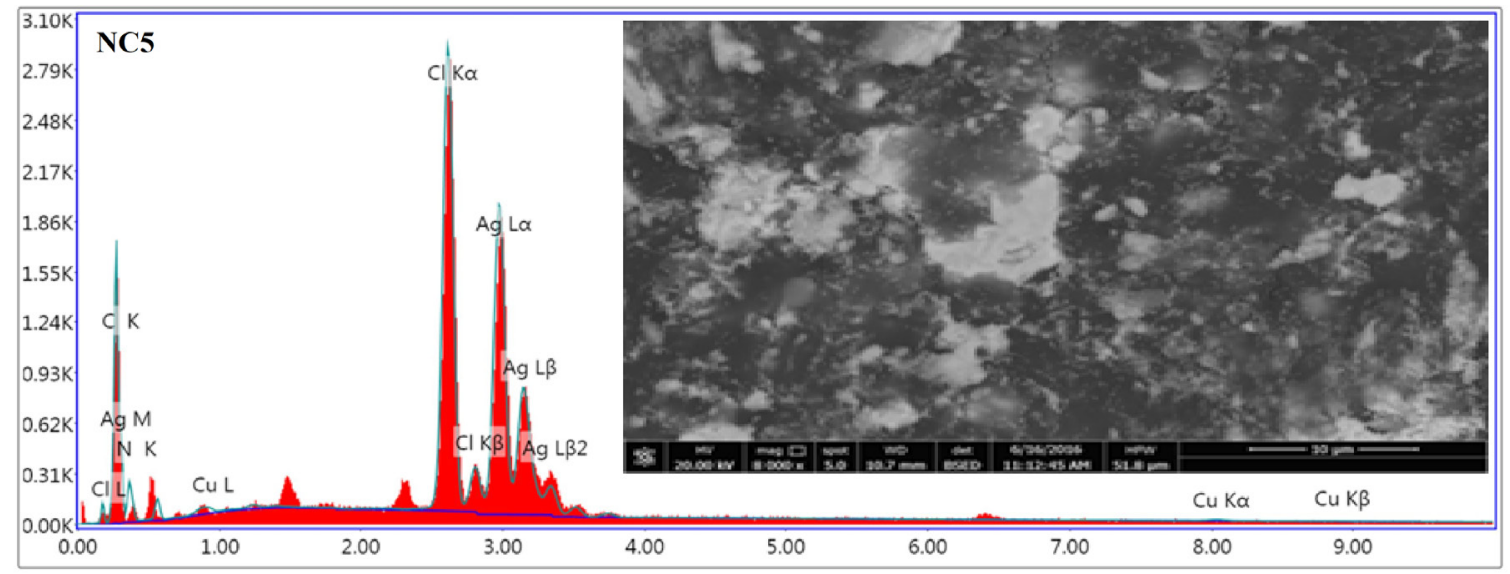

Lsec: 30.00 Cnts $0.000 \mathrm{keV}$ Det: Octane Pro Det Reso

Fig. 7. SEM images and EDAX analysis of PANI/(Cu/Ag) NCs.

Egypt. J. Chem. 61, No. 5 (2018) 
TABLE 4. Electrical conductivity of PANI /(Cu/Ag) NCs.

\begin{tabular}{|c|c|}
\hline NCs & DC $\sigma(\mathrm{S} / \mathrm{m})$ \\
\hline $\mathrm{NC} 1$ & 0.52 \\
\hline $\mathrm{NC} 3$ & 9.22 \\
\hline NC5 & 13.00 \\
\hline
\end{tabular}

conductivity. It is worthy to mention that $\mathrm{Ag}$ in $\mathrm{Cu} / \mathrm{Ag}$ bimetallic nanostructure enhances the electrical migration of $\mathrm{Cu}$ ions, leading to high conductivity [27]. Also coating the $\mathrm{Cu} / \mathrm{Ag}$ NPs by PANI protect the $\mathrm{Cu}$ from oxidation.

\section{Antimicrobial activities (antibacterial and antifungal activities)}

The antimicrobial activities of $\mathrm{Cu} / \mathrm{Ag}$ NPs, PANI and NCs relative to standards are represented in Table 5 and Fig. 8. Cu/Ag NPs have medium antibacterial activity to Escherichia coli (G-), while high inhibition is observed towards staphyloccus aureus $(\mathrm{G}+)$. They also showed high activity to both Aspergillus flavus and Candida albinos fungus, respectively. The antimicrobial activity of them stems from the superior activity of their NPs, allowing them to penetrate the cell wall and kill the microbe, also they generate metal ions in presence of oxygen that can reach the bacteria which NPs can not reach [41,42]. Moreover, as Ag NPs has higher antimicrobial activity than $\mathrm{Cu}$ NPs, the increase in $\mathrm{Ag}$ to $\mathrm{Cu}$ ratio from $\mathrm{C} /$ A1 to C/A5 contributed to rise the antibacterial activity, which can be explained by the formation of free radicals of $\mathrm{Ag}$ that participate in damaging the microbial cell [43]. It is well known that PANI possesses reasonable antimicrobial and antifungus resistance. Results revealed that doped PANI by hydrochloric acid showed medium and high activity to Escherichia coli (G-) and Aspergillus flavus, respectively, with no activity against Staphylococcus aureus $\left(\mathrm{G}^{+}\right)$and Candidaa albicans (fungus). Therefore, in NCs, PANI layer encapsulating $\mathrm{Cu} / \mathrm{Ag}$ NPs decreased their antimicrobial activity, as PANI controls the release of metal ions by slowing them down, accordingly excess toxicity of the environment is avoided [41]. The NCs showed medium antibacterial activities towards both G- and G+ bacteria, with slight increase from $\mathrm{NC} 1$ to $\mathrm{NC} 5$, whereas they showed excellent antifungal activity towards Aspergillus flavus. They exhibited the same inhibition percentages towards Aspergillus flavus as their counterparts $\mathrm{Cu} / \mathrm{Ag}$ NPs and also as PANI manifested excellent activity. However NCs are inefficient towards Canaida albicans due to the nil activity of PANI layer.

\section{Conclusion}

In this article bimetallic $\mathrm{Cu} / \mathrm{Ag}$ core shell NPs were prepared using electroless plating of Ag NPs on $\mathrm{Cu}$ NPs, by reduction of $\mathrm{AgNO}_{3}$ in dispersion of $\mathrm{Cu}$ NPs. Different weight ratios of $\mathrm{AgNO}_{3}$ to $\mathrm{Cu}$ NPs were used $(1: 1,3: 1$, and $5: 1)$. PANI/ $(\mathrm{Cu} / \mathrm{Ag}) \mathrm{NCs}$ were synthesized by oxidative polymerization of aniline in dispersion of the prepared core shell NPs. XRD, FTIR, TEM, SEM and EDAX were used for characterization of both $\mathrm{Cu} / \mathrm{Ag}$ NPs and their corresponding NCs.

XRD data and TEM images of $\mathrm{Cu} / \mathrm{Ag}$ NPs indicated the formation of sperical nanoparticles (10-30 nm) of crystalline bimetallic structure. SEM micrographs showed that Ag coated moderately $\mathrm{Cu}$ NPs, while EDAX data revealed that thin layer of $\mathrm{Ag}$ increased from 38.1(of C/ A1) to 68.7 (of $\mathrm{C} / \mathrm{A} 5$ ) while $\mathrm{Cu}$ decreased from 61.9 to 31.3 weight percent, respectively.

EDAX data of NCs revealed that PANI mostly coated the uncovered $\mathrm{Cu}$ NPs, such that its content nearly diminished ( $\approx 0.5$ weight percent). No marked variation of shell surface composition for all synthesized NCs was observed, as PANI and $\mathrm{Ag}$ weight percent ranged from (60-63.5) and (35.8 to 39) respectively.

The electrical conductivity of NCs increased from $0.52 \mathrm{~S} / \mathrm{m}$ (in $\mathrm{NC} 1$ ) to $13 \mathrm{~S} / \mathrm{m}$ (in $\mathrm{NC5}$ ) with increasing of $\mathrm{Ag}$ content. They can be used as sensors and as protective coating on 

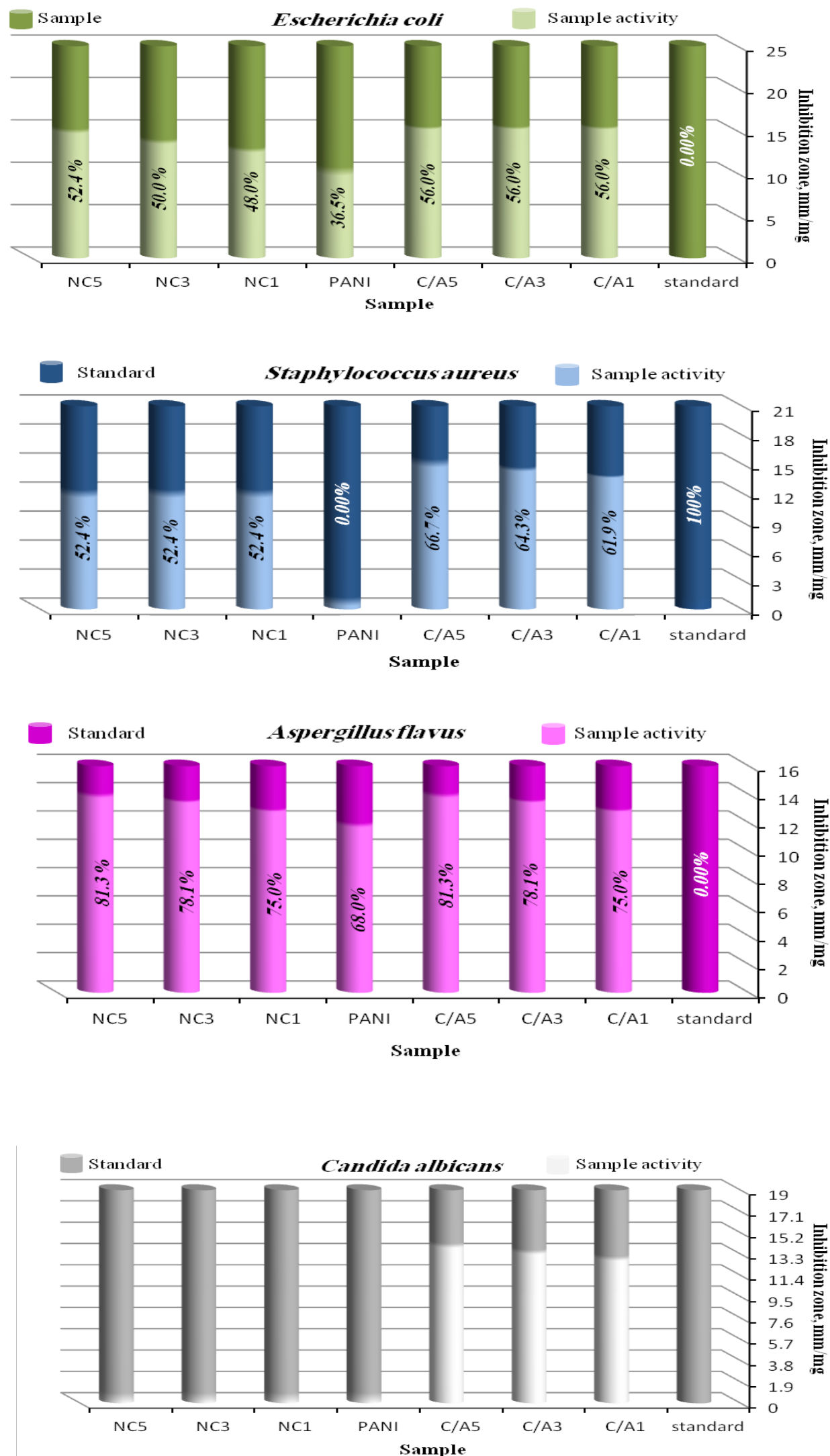

Fig. 8. Antimicrobial and antifungal activities of NPs, NCs and pure PANI and their \% in comparison to standards (ampicillin antibacterial agent and amphotericin $B$ antifungal agent).

Egypt. J. Chem. 61, No. 5 (2018) 
TABLE 5. Antibacterial and antifungal activity of different prepared Cu/Ag NPs, PANI and synthesized NCs.

\begin{tabular}{|c|c|c|c|c|c|c|c|c|c|}
\hline & & & & ibitior & zone diame & $r(\mathrm{mn}$ & mg sample & & \\
\hline & Sample & Esch & ia coli & $\begin{array}{r}\text { Stap } \\
\text { au }\end{array}$ & $\begin{array}{l}\text { lylococcus } \\
\text { eus }\left(G^{+}\right)\end{array}$ & Asper & $\begin{array}{l}\text { us flavus } \\
\text { gus) }\end{array}$ & $\begin{array}{r}\mathrm{C} \\
\text { albica }\end{array}$ & $\begin{array}{l}\text { Indidaa } \\
\text { is (Fungus) }\end{array}$ \\
\hline & Control : DMSO & & & & 0.0 & & 0 & & 0.0 \\
\hline & $\begin{array}{c}\text { Ampicillin antibacterial } \\
\text { agent }\end{array}$ & & & & 21 & & - & & -- \\
\hline 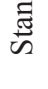 & $\begin{array}{l}\text { Amphotericin B } \\
\text { Antifungal agent }\end{array}$ & & & & -- & & 6 & & 19 \\
\hline & & & $\%$ to & & $\%$ to & & $\%$ to & & $\%$ to \\
\hline & $\mathrm{C} / \mathrm{A} 1$ & 14 & $\begin{array}{l}\operatorname{tandard} \\
56\end{array}$ & 13.0 & $\begin{array}{c}\text { Standard } \\
61.9\end{array}$ & 12.0 & $\begin{array}{c}\text { Standard } \\
75.0\end{array}$ & 12.0 & $\begin{array}{c}\text { Standard } \\
63.2\end{array}$ \\
\hline & $\mathrm{C} / \mathrm{A} 3$ & 14 & 56 & 13.5 & 64.3 & 12.5 & 78.1 & 12.5 & 65.8 \\
\hline & $\mathrm{C} / \mathrm{A} 5$ & 14 & 56 & 14.0 & 66.7 & 13.0 & 81.3 & 13.0 & 68.4 \\
\hline & PANI pure & 9 & 36 & 0.0 & 0.0 & 11.0 & 68.8 & 0.0 & 0.0 \\
\hline & $\mathrm{PANI} /(\mathrm{C} / \mathrm{A} 1) \mathrm{NC} 1$ & 12 & 48 & 11.0 & 52.4 & 12.0 & 75.0 & 0.0 & 0.0 \\
\hline & $\mathrm{PANI} /(\mathrm{C} / \mathrm{A} 3) \mathrm{NC} 3$ & 12.5 & 50 & 11.0 & 52.4 & 12.5 & 78.1 & 0.0 & 0.0 \\
\hline & $\mathrm{PANI} /(\mathrm{C} / \mathrm{A} 5) \mathrm{NC} 5$ & 13 & 52 & 11.0 & 52.4 & 13.0 & 81.3 & 0.0 & 0.0 \\
\hline
\end{tabular}

Values with respect to standards, $30 \%$, from $30-60 \%$ over $60 \%$, and over $75 \%$ are considered weak, medium, high and excellent respectively.

steel substrate from corrosion. $\mathrm{Cu} / \mathrm{Ag} \mathrm{NPs}$ and their corresponding NCs showed medium-high antibacterial and high antifungal activities, recommending them to be applied as biosensors, detectors and in food packaging field.

\section{Acknowledgment}

Great appreciation to National Research Center for the financial support of this research article derived from project No.10050408 (20132016). Deep thanks to Prof. Dr. Mohamed Hashem vice president of National Research Center of research affairs and international relations for his continuous support.

\section{References}

1. Alagarasi A., Introduction to Nanomaterials, 1-76 (2011) (available from http:// www. nccr. (iitmin /2011).

2. Nanotechnology, Wikipedia, the free encyclopedia (2014).

3. Mohsen R. M., Selim M. M., Aby- Ayana Y. M., Morsi S. M., Ghoneim A. M. and El-Sawy S. M., Nanotechnology and nanomaterials, Chapter 7 in Nanomaterials \& Nanotechnology, Editor Prof. Waqar Ahmad, Publisher One Central Press (OCP)

$$
\text { 145-179 (2016). }
$$

4. Kunzo P., Polyaniline nanoparticles: Composite for gas sensors preparation and characterization, Ph.D. Thesis from STU - FEI, Bratislava (2015).

5. Park S. J., Kwon O. S., Lee J. E., Jang J., and Yoon H., Conducting polymer-based nanohybrid transducers: A potential route to high sensitivity and selectively sensors, Sensors, 14, 3604-3630 (2014).

6. Mukherjee S., Meshik X., Choi M., Farid S., Datta D., Lan Y., Poduri S., Sarkar K., Baterdene U., En Huang C., Yu Wang Y., Burke P., A graphene and aptamer based liquid gated FET-Like electrochemical biosensor to detect adenosine triphosphate, Leee Transaction Nanobioscience, 14 (2015).

7. $\mathrm{Li} \mathrm{J}$. and $\mathrm{Wu}$ N., Biosensors Based On Nanomaterials and Nanodevices in Nanomaterials and their Applications book series, Published by CRC Press Taylor Franc Group (2017).

8. Abdullah H., Naim N. M., Azmy N. A., and Hamid A. A., PANI-Ag-Cu nanocomposite thin films based impedimetric microbial sensor for detection of E. coli bacteria, J. of Nanomaterials, 2014, 1-8 (2014).

Egypt. J. Chem. 61, No. 5 (2018) 
9. John S., Joseph A., Jose A. J., and Narayana B., Enhancement of corrosion protection of mild steel by Chitosan/ zinc oxide nanoparticle composite membrane, Progress in Organic Coating, 84, 2834 (2015).

10. Tsirimpis A., Kartsonakis I., Danillidis I., Liatasi P., Kordas G., Synthesis of conductive polymeric composite coatings for corrosion protection applications, Progress in Organic Coatings, 67, 389-397 (2010).

11. Giri S., Ghosh D., and Das C.K., In situ synthesis of cobalt doped polyaniline modified graphene composites for high performance supercapacitor electrode materials, Journal of Electroanalytical Chemistry, 697, 32-45 (2013).

12. Pande S., Singh B.P., Mathur R.B., Dhami TL., Saini P., Dhawan S.K., Improved of electromagnetic interference shielding properties of MWCNT- PMMA Composites using layered structures, Nanoscale Research Letters Journal, 4, 327-334 (2009).

13. Chandra S., Kunmar A., Tomar P. K., Synthesis and characterization of copper nanoparticles using reducing agent, Journal Saudi Chemical Society, 18,149-153 (2014).

14. Das T. K., Prusty S., Review on conducting polymers and their applications, Polymer Plastics Technology and Engineering, 51, 1487-1500 (2012).

15. Ebrahimi G., Rezaei F., Neshati J., Effect of HCldoped polyaniline nanoparticles on the corrosion protection properties of epoxy coating, Home, 36, 1674-1681 (2015).

16. Grouchko M., Kamyshny M., Magdassi S., Formation of air copper-silver -stable core-shell nanoparticles for inkjet printing, J. Mater. Chem., 19, 3057-3062 (2009).

17. Mansouri S., Ghader S., Experimental study on effect of different parameters on size and shape of triangular silver nanoparticles prepared by a simple and rapid method in aqueous solution, Arabian Journal of Chemistry, 2 47-53 (2009).

18. Merza K. S., Al-Attabi H. D., Abbas Z. M., Yuser H. A., Comparative study on methods for preparation of gold nanoparticles, Green on Sustainable Chemistry, 2, 20-28 (2012).

19. Sui N., Li X., Liu M., Xiao H., Jiang Y., Zhao J., Yu W. W., Nobel metals nanoparticles synthesized by chemical reduction; under graduate Experiments

Egypt. J. Chem. 61, No. 5 (2018) for nanomaterials, Journal of Laboratory chemical Education, 2, 28-32 (2014).

20. Johanna F., Production of $\mathrm{Co}, \mathrm{Ni}$, and $\mathrm{Cu}$ nanoparticles by hydrogen reduction. Thesis for the degree Ph.D of doctor of science in Technology to be presented with due permission for public examination and debate in auditorium F239a at Aalto University School of Science and Technology (Espoo, Finland), on the 27th of August, (2013).

21. Khaydarov R. A., Khaydarov R. R., Gapurova O., Estrin Y., Scheper T., Electrochemical method for the synthesis of silver nanoparticles, $J$. Nanoparticles Research, 11, 1193-1200 (2009).

22. Mafune F., Kohno J.-Ya, Takeda Y., and Kondow T., Structure and stability of silver nanoparticles in aqueous solution produced by laser ablation, Journal of phys. Chem. B, 104, 8333-8337 (2000).

23. lagashetty A., Havanoor V., Basavaraja S., Balaji S. D. and Venkataraman A., Microwave assisted route for synthesis of nanosized metal oxides, Science Technology of Advanced Materials, 8, 484-493 (2007).

24. Kulkarni N. and Muddapur U., Biosynthesis of metal nanoparticles: A review, Journal of Nanotechnology, 2014 (2014).

25. Kumar B., Smita K., Cumbal L., Debut A., and Pathak R. N., Sonochemical synthesis of silver nanoparticles using starch, Bioinorganic Chemisry and Applications, 2014 (2014).

26. Gasaymeh S. S., Radiman S., Heng L.Y., Saion E. and Saeed G.H, M., Synthesis and characterization of silver/polyvinylpiyrolidone (Ag/PVP) nanoparticles using gamma irradiation technique, $J$. of Applied Sciences, 7, 892-901 (2010).

27. Salam A. A., Singaravelan R., Vasanthi P., Alwar S. B., Electrochemical fabrication of $\mathrm{Ag}-\mathrm{Cu}$ nanoalloy and its characterization: An investigation, J. of Nanostructure in Chemistry, 5, 383-392 (2015).

28. Valodkar M., Modi S., Pal A., Thakore S., Synthesis and antibacterial activity of $\mathrm{Cu}, \mathrm{Ag}$ and $\mathrm{Cu}-\mathrm{Ag}$ alloy nanoparticles: a green approach, Mat. Res. Bull. 46, 384-389 (2011).

29. Taner M., Sayar N., Yulug I. G., Suzer S., Synthesis, characterization and antibacterial investigation of silver-copper nanoalloys, $J$. Mater. Chem., 21,13150-13154 (2011). 
30. Bernard V., Zobac O., Sopousek J., Mornstein V., $\mathrm{AgCu}$ bimetallic nanoparticles under effect of low intensity ultrasound: the cell viability study in vitro. J. Cancer Res. (2014). doi:10.1155/2014/97176.

31. Li Y., Lu Y., Chou K., Liu F., Synthesis and characterization of silver-copper colloidal ink and its performance against electrical migration. Mat. Res. Bull. 45, 1837-1843 (2010).

32. Magdassi S., Grouchko M. and Kamyshny A., Copper nanoparticles for printed electronics: Routes towards achieving oxidation stability, Materials, 3, 4626-4638 (2010).

33. Rousse C., Josse J., Mancier V., Levi S., Gangloff S. C., and Fricoteaux P., Synthesis of coppersilver bimetallic nanopowders for a biomedical approach; study of their antibacterial properties, RSC Advances, 6, 50933-50940 (2016).

34. Paszkiewicz M., Gołąbiewska A., Rajski L., Kowal E., Sajdak A., and Medynska A. Z., Synthesis and characterization of monometallic $(\mathrm{Ag}, \mathrm{Cu})$ and bimetallic $\mathrm{Ag}-\mathrm{Cu}$ particles for antimicrobial and antifungal applications, $J$. of Nanomaterials, 2016, 1-11 (2016).

35. Cioffi N., Ditaranto N., Torsi L., Picca R. A., Giglio E. De, Sabbatini L., Novello G. L., Zacheo T. B., Zambonin P. G., Cioffi N., Synthesis, analytical characterization and bioactivity of $\mathrm{Ag}$ and $\mathrm{Cu}$ nanoparticles embedded in poly-vinylmethyl-ketone films, Analytical and Bioanalytical Chemistry, 382, 1912-1918 (2005).

36. Hall W. H., Strain lattice equation, Acta Metall. 1, 22-31 (1953).
37. Bauer A., Kirby W., Sherris C., Turck M., Antibiotic susceptibility testing by a standardized single disk method, American J. of Clinical Pathology. 45, 493-496 (1966).

38. Leibowitz L. D., Ashbee H. R., Evans E. G. V., Chong Y., Mallatova N., Zaidi M., Gibbs D., and Global, A two year global evaluation of the susceptibility of Candida species to fluconazole by disk diffusion, Diagnostic Microbiology Infect. Disease, 40, 27-33 (2001).

39. Arunachalam K.D., Annamalai S.K., Hari S., One step green synthesis and characterization of Leaf extract mediated, biocompatible silver and gold nanoparticles from a memecylon umbellatum, Nanomedicine, 8, 1307-1315 (2013).

40. Kelmani R. C., Ashajyothi C., Oli A. K., Potential bactericidal effect of silver nanoparticles synthesised from enterococcus species, Oriental Journal of Chemistry, 30, 1253-1262 (2014).

41. Potera C., Understanding the germicidal effects of silver nanoparticles, Forum, 120 (2012).

42. Raffi M., Mehrwan S., Bhatti T. M., Akhter J. I., Hameed A., Yawar W., Hasan M. M., Investigations into the antibacterial behavior of copper nanoparticles specificity in antimicrobial activity of silver and copper nanoparticles, Annals of Microbiology, 60, 75-80 (2010).

43. Dakal T.C., Kumar A., Majumdar R.S., and Yadv V., Mechanistic Basis of Antimicrobial Actions of Silver Nanoparticles, Front Microbiol, 7, 1831 (2016).

(Received 28/5/2018; accepted 18/7/2018) 


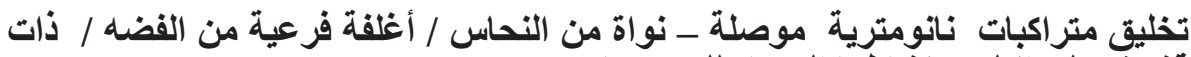

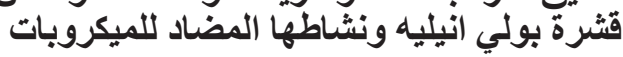

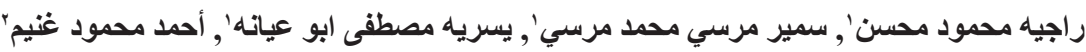

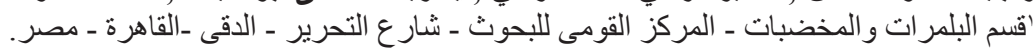

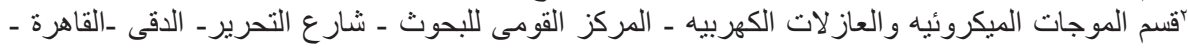

تشتهر المعادن بكل من قوة التوصيل الكهربى ومقاومة الميكروبات ويحتل معدن الفضه المكانه الأولى يليه

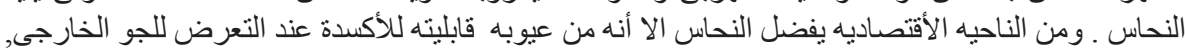

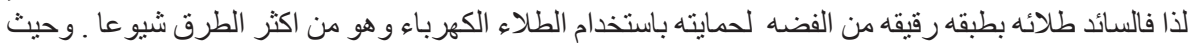

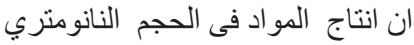

اجتذب اهميه قصوى فى العالم لخو اصها المتميزة التى تفوقت عنها فى الحجم العادى للتطبيقات المختلفه

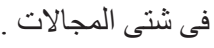

يهدف هذا البحث الى تحضير وتقييم متر اكبات بوليمريه نانومتريه موصله وذات مقاومه للميكروبات. ويمكن تقسيم العمل بهذا البحث الى لى قسمين:

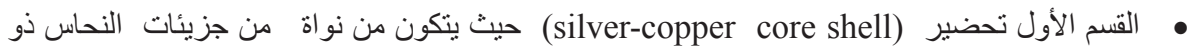
الحجم النانومتري , تغطى بجزيئات الفضه النانومتربة الحجم بالطلاء دون استخدام الكهرباء

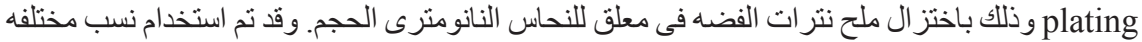
بالوزن من نترات الفضه الى النحاس.

• القسم الثانى تحضير منر اكب بوليمرى موصل من الأنيلين بنسب مختلفه مع المزيج المعدنى النانومنري

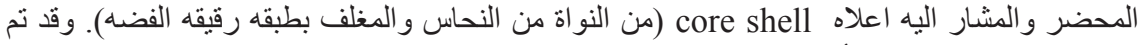

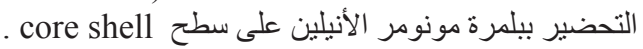

وتم تقييم جميع الخو اص لكل من المزيج و المنر اكب البوليمرى الموصل بالأشعة السينيه XRD و الاشعه

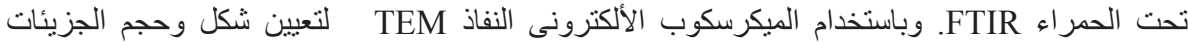

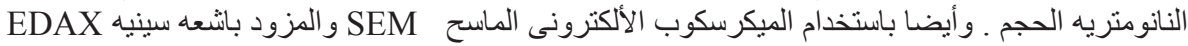
لار اسة تركيب السطح وتعيين نسب المكونات المختلفه.

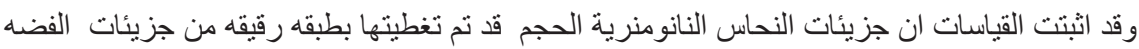

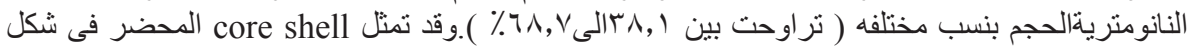

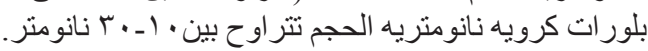

وقد تم الحصول على متر اكبات بوليمرية موصله نانومتريه بتغطية اسطح core shell بالبولى انبلين

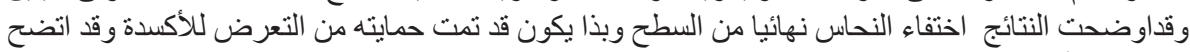

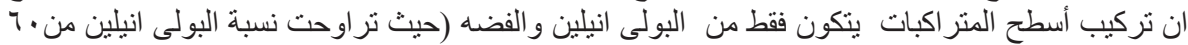

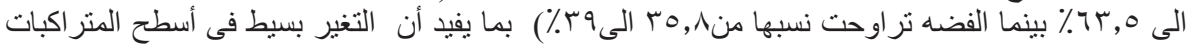

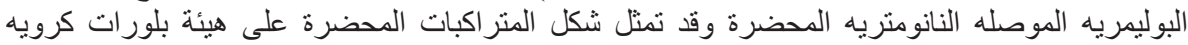

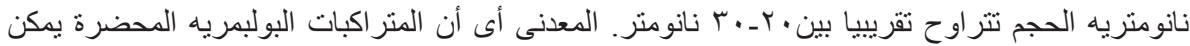

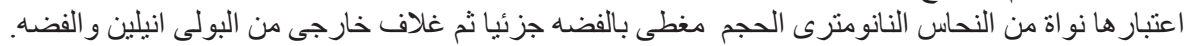

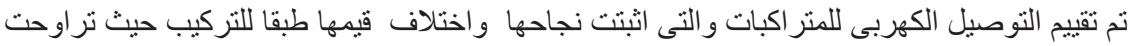

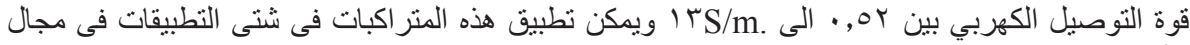

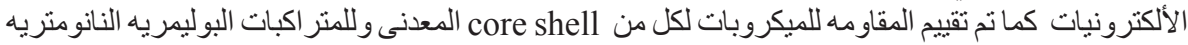

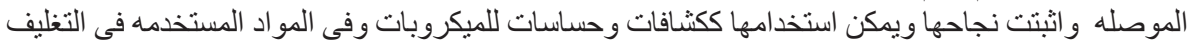

